\title{
Medicine and Art
}

\section{Art in hospitals}

\section{Funding works of art in new hospitals}

\author{
JEREMY HUGH BARON, LESLEY GREENE
}

Throughout the world new hospitals have been designed and built for high quality medical care. Few have been designed to be beautiful. We believe each hospital should enhance the lives of patients, visitors, and staff by including works of art.

Works of art cost money, yet money spent on contemporary works provides employment for painters, sculptors, and craftsmen and also for the manufacturers of their materials. Where is this money to come from when health services are starved of capital and revenue?

The beautification of old hospitals is discussed elsewhere.' In the first part of this article JHB explores three methods of funding works of art in new hospitals and in the second part LG describes the mural scheme run by the King's Fund and the Greater London Arts Association (GLAA).

\section{Percentage laws}

The most effective way of ensuring that major new public buildings have works of art is by legislation enforcing the expenditure of a certain percentage of the building cost on art. Norway, the Netherlands, the USA, Canada, France, Italy, and West Germany all have these sorts of schemes. ${ }^{2}$

In Norway, for example, a Norwegian Fund for Art in New State Buildings is funded by $1 \%$ of the cost of all state buildings. The money must be used to improve the working environment of state employees and visitors to public buildings, as well as ensuring work for Norwegian artists. The fund appoints two artist consultants to each local building project committee. This committee has a free hand if the arts allocation is less than $\mathrm{Kr}$ 50000 (about $£ 5000$ ) but above that figure it must have its decorative plan approved by the national fund. The artists must be Norwegians living and working in Norway, and they are commissioned either personally or by closed competition from a short list of four. Rarely, work may be selected through open competition or bought directly from the artists. The new 1139 bed Haukeland Sykehus in Bergen cost $\mathrm{Kr} 2055 \mathrm{~m}(£ 190 \mathrm{~m})$ and was awarded a government art grant of $\mathrm{Kr} 1.5 \mathrm{~m}(£ 138000 ; 0.15 \%)$ for the central block. The hospital hopes to obtain a similar sum from the county for the non-university buildings. The budget has been divided between working units, each of which has a theme and a particular artist or group of artists.

The Netherlands also has a law allocating $1 \%$ of the cost of the raw materials of a building to works of art. The commissioning team of the building controls the budget, but its plan has to be

Department of Surgery, Royal Postgraduate Medical School, Hammersmith Hospital, London W12 0HS

J H BARON, DM, FRCP', senior lecturer

Public Art Development Trust, London EC1R 4TD

LESLEY GREENE, MLITT, director approved by the Ministry of Education and its arts advisers, who vet the work for quality and price. The Academisch Ziekenhuis of the University of Amsterdam was built in 1974-84 for Dfl $1000 \mathrm{~m}$ $(£ 230 \mathrm{~m})$, of which the arts budget was Dfl $2 \cdot 4 \mathrm{~m}$ ( $\$ 550000)$ $(0.24 \%)$. The commissioning team, comprising the director of organisation and planning and the professors of surgery and immunology, planned a total decorative scheme with a didactic theme-postwar movements in the arts in the Netherlands. Each movement is represented in a separate unit; the hospital includes comprehensive overviews of the zero movement, experimental expressionism, informal art, lyric abstract work, new figuratism, constructivism, and neo-expressionism. The hospital currently has 4600 pictures, mostly bought from the original budget but some lent by doctors (to the value of Dfl $150000, £ 35000$ ) or given by patients. Others are borrowed from the half million that the state has acquired from its 3000 salaried artists. The hospital pays a full time curator.

In New York an executive order signed by the mayor in 1965 encouraged city agencies, including public hospitals, to spend up to $1 \%$ of construction costs on fine art and to display art in areas accessible to the public. The city's fiscal crises prevented this spending for some years. In 1982, however, a law came into force that stipulated that a certain percentage of capital construction costs should be used to purchase art-up to a maximum of $\$ 400000(£ 320000)$ for any individual building, with a limit of $\$ 1.5 \mathrm{~m}(£ 1.2 \mathrm{~m})$ a year for all art in municipal buildings in New York. The city's Department of Cultural Affairs appoints a separate panel for each eligible project and monitors the selection of artists and expenditure. Five of the newest city hospitals have received municipal funds for the arts.

Woodhull Hospital Centre-The 900 bed Woodhull Hospital Centre in Brooklyn opened in 1983 with a final arts budget of

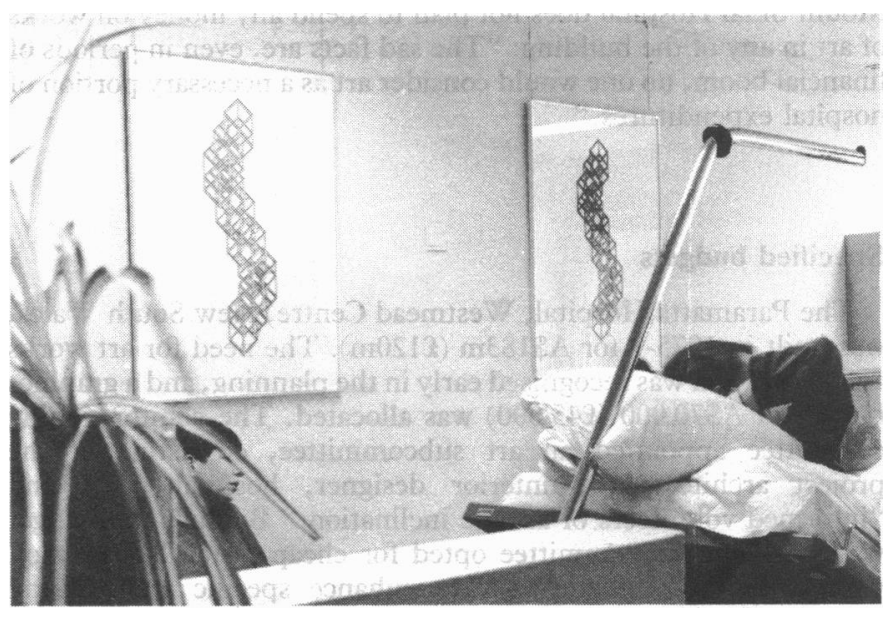

Prints in the Academisch Ziekenhuis, Amsterdam. 


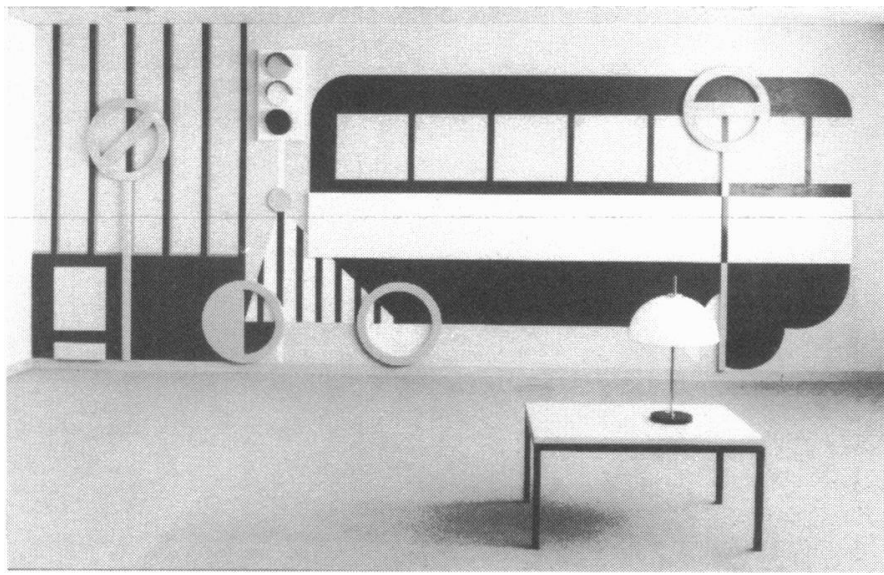

Mural in the children's department of the Westmead Centre, New South Wales.

$\$ 260000$ (£208000) (0.18\%). The hospital was deliberately designed not to have the usual sterile image of a public institution, and almost all the money was spent on original prints in corridors, patient areas, and conference rooms. The selection committee, chaired by the retired director of the Whitney Museum of American Art, tried to find artists belonging to the ethnic minorities in the hospital's catchment area. The budget therefore included only a few large commissions such as a pair of tapestries in the main lobby, a canvas and aluminium ceiling structure, 13 large paintings, one frieze of acrylic panels, and a giant fibreglass apple in the cafeteria. The framing cost as much as the prints because each was mounted on acid free board in a plexiglass box bolted on a wood frame to the wall. These officially provided pictures stimulated other departments to find their own funds for further pictures: paediatrics employed an artist to paint Mickey Mouse murals.

Bellevue Hospital (1200 beds) occupies a 25 storey building opened in 1975. The four top floors (prison and mental health services) are due to open in 1985, and have an arts budget of $\$ 210000$ ( $\$ 170000)$. Some 310 works have been bought by the voluntary fine arts board of eight visual arts professionals and two Bellevue doctors. There is also a full time arts administrator paid from the hospital budget who collaborates with an environmental psychologist and a designer. On the lower floors, which are not eligible for municipal funding, donations have been sought from artists, galleries, and collectors. Artists representing Environmental Arts Inc (a non-profit organisation) have sponsored Robert Taplin's 22 foot high kinetic sculpture outside the emergency entrance. One problem of art in public settings is that the identification labels of artists and titles often disappear unless they too are bolted to the walls.

The non-municipal hospitals of New York are not entitled to city funds and rarely make provisions for art. Certainly the new Mount Sinai Hospital does not plan to spend any money on works of art in any of the building: "The sad facts are, even in periods of financial boom, no one would consider art as a necessary portion of hospital expenditures."

\section{Specified budgets}

The Paramatta Hospital, Westmead Centre, New South Wales, was built in $1975-9$ for $A \$ 183 \mathrm{~m}(£ 120 \mathrm{~m})$. The need for art works and decoration was recognised early in the planning, and a graphics budget of $\mathrm{A} \$ 70000$ ( $\$ 45000)$ was allocated. The commissioning committee appointed an art subcommittee, consisting of the project architect, the interior designer, hospital staff, and "informed volunteers of artistic inclination." Because the budget was small the subcommittee opted for cheap tasteful decoration with areas of local emphasis to enhance specific architectural features. Thus thematic wall hangings were commissioned from a local weaver for the main entrance foyer $(A \$ 14000, £ 9,200)$ and the chapel $(A \$ 5,000, £ 3,200)$, with a mural for the children's play area $(A \$ 10,000, £ 6,600)$. Because there was no money for prints the subcommittee held an open competition for the best print, the entry fee to be the print. The prizes and expenses were gifts and the framing costs came out of the graphics budget. Over 400 prints were donated (to a value of $A \$ 17000, £ 11000$ ) despite criticism by gallery owners.

At Jorvi district hospital, just outside Helsinki, about FMk 50000 (£6250)(0.025\%) was allocated for works of art, with a similar sum to be spent in each subsequent year. The works are purchased by the municipal consortium from a selection by the medical director and are all by artists living in the hospital's catchment area.

\section{Ad hoc funding: the British scene}

There have been several attempts in Britain to allot a percentage of building costs to works of art. In 1947 the Ministry of Education authorised local authorities to spend up to $0.3 \%$ of building costs of new schools on works of art. Hertfordshire's chief education officer seized on this opportunity and the county's school construction programme fully operated this system until the early 1950 s, installing, for example, the Henry Moore "Family" at Barclay School, Stevenage New Town. The Department of the Environment does allow $1 \%$ of construction costs of government buildings for works of art, with a current ceiling of $£ 25000$. This sum can be exceeded with special permission for an especially prestigious building, and any work of art costing more than $£ 500$ must be approved by the minister.

It is almost unheard of for a health authority to earmark money for the arts for its new buildings, though special trustees are sometimes willing to finance art in new hospital schemes from their endowment funds.

The new wing of St Thomas’s Hospital cost about $£ 25 \mathrm{~m}$ in 1975 . Two years earlier the then board of governors had had the foresight to set aside $£ 26000$-about $0 \cdot 1 \%$-for buying modern works of art for the new buildings. The architect and two senior hospital consultants went around the London galleries and bought a surprisingly large number of excellent prints, which were hung when the new wing was opened. Moreover, the architect persuaded the Arts Council to contribute $\$ 5000$ towards six enamelled panels-the "St Thomas's Enamels" by Robyn Denny - that were incorporated into the reception area. The Tate Gallery made an indefinite loan of its Naum Gabo "Torsion" fountain for installation in the hospital gardens. Today the special trustees pay for a part time art historian responsible for both the modern and historic collections, and provide an annual budget of $£ 4000$ for restoring and resiting works-for example, the Victorian decorated wall tiles-together with $\$ 2000$ a year for new purchases, and supplementary grants in response to special requests from departments or wards.

The Royal Liverpool Hospital was also given a specific arts budget of $£ 17000$. The major work of art is the Bridget Riley project commissioned by the Arts Council, Merseyside County Council, and the hospital endowment fund:

I have tied the organisation of the colours into the given architectural framework of the corridors. Incorporating the trolley band, increasing the black skirting board, taking the floor design into account and echoing these with a black band at what might be described as cornice level, gave me a skeleton upon which I could hang the bands of colour which bind the space together visually, which clothe it and "wrap around" it a feeling of comfort. It is not in any way a painting or even a mural, it is a decoration in the classic sense of the word: that is an articulation of the bones of architecture into a flowing environment, a space that one can pass through with a sense of ease and movement. Initially I planned to paint the decoration on to the walls, but this proved impracticable. Eventually Graham Henderson hand painted it by silkscreen on to vinyl sections, which have the added advantages of being replaceable, washable, fireproof, and inexpensive.

Other hospitals in which small sums were set aside for art 


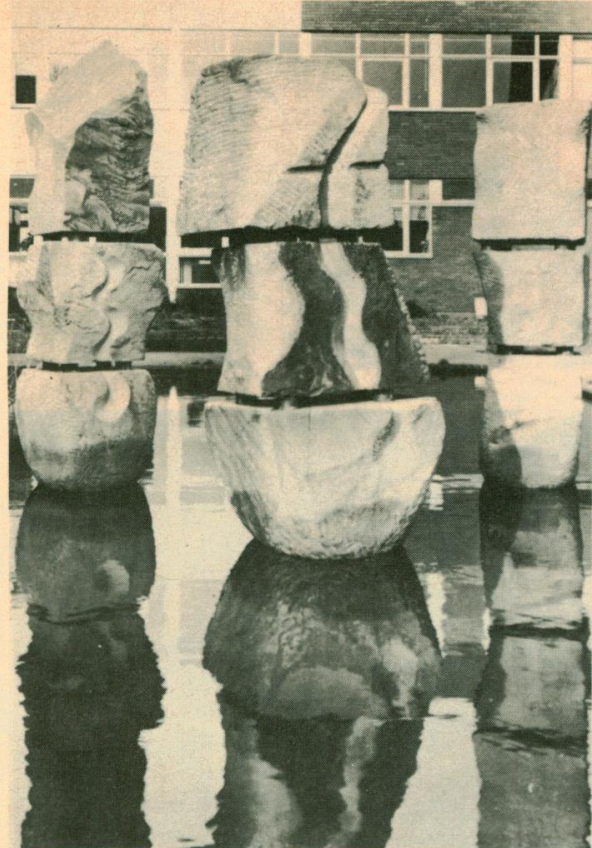

Above: "Three Carved Stones" by Gilbert Ward at Darlington Memorial Hospital. Top right: Screenprints by Herbert Bayer in the maternity unit at the John Radcliffe Hospital, Oxford. Bottom right: Mural of Old Hammersmith in Charing Cross Hospital, London, by Julian Trevelyan and Mary Fedden.
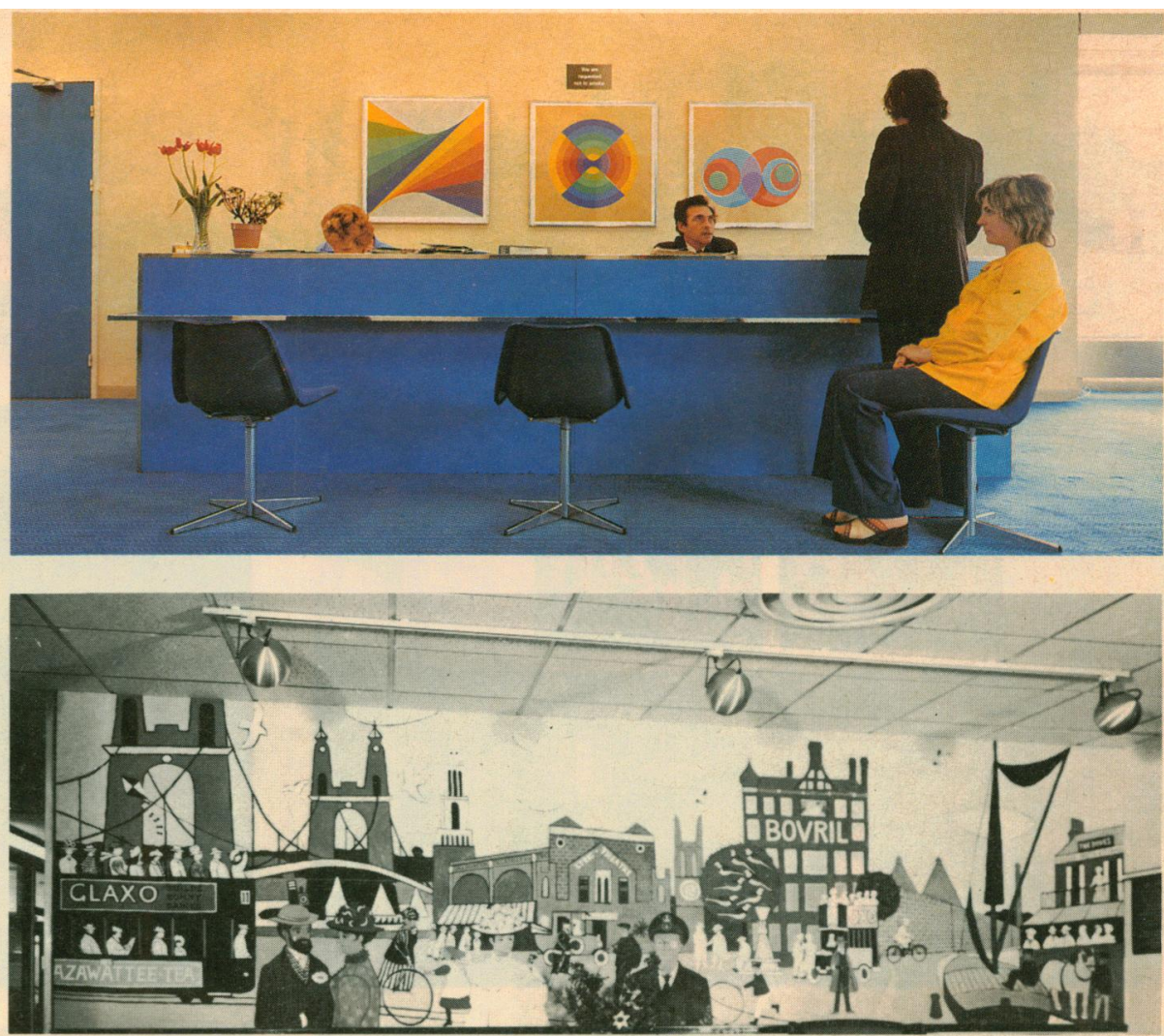

include Leicester Royal Infirmary and the John Radcliffe Hospital, Oxford, in both of which the original sums have been supplemented by trust funds. At the new Addenbrooke's Hospital in Cambridge there was no specific art budget, but equipment schedules for the new departments allowed between 0.005 and $0 \cdot 1 \%$ for decorative features. This sum went on objects like plant troughs.

Europe's first low energy hospital is being built at Newport, Isle of Wight. Both the architects and the DHSS are keen that the work of artists and craftsmen form an integral part of the new buildings, and this development provided the DHSS with the opportunity to assess how all the arts may contribute to an entire health district, drawing on local, regional, and national resources. A feasibility study funded by the DHSS, the Arts Council, Southern Arts Association, and the Calouste Gulbenkian Foundation produced a report ${ }^{\varsigma}$ that might act as a model district arts policy for the NHS generally; one of its recommendations is that each district should have its own arts coordinator.

But these schemes are the exception. Most new hospitals set nothing aside for works of art, and some have later tried to rectify this omission by efforts locally. Northwick Park Hospital, the Royal Free Hospital, St George's Hospital, and Charing Cross Hospital are examples of London hospitals that have set up art committees and raised funds to buy works of art-from the Arts Council, industry, and leagues of friends. Charing Cross Hospital managed to borrow a Henry Moore sculpture, which reclines in the pool in front of the hospital, and in 1980 Julian Trevelyan and Mary Fedden painted "Old Hammersmith" in the geriatric department. Keith Grant designed a mosaic "The Magic Mountain" for the laboratory block corridor, executed by young people under the Manpower Services Commission scheme.

In Nottingham the Queen's Medical Centre set up a joint arts

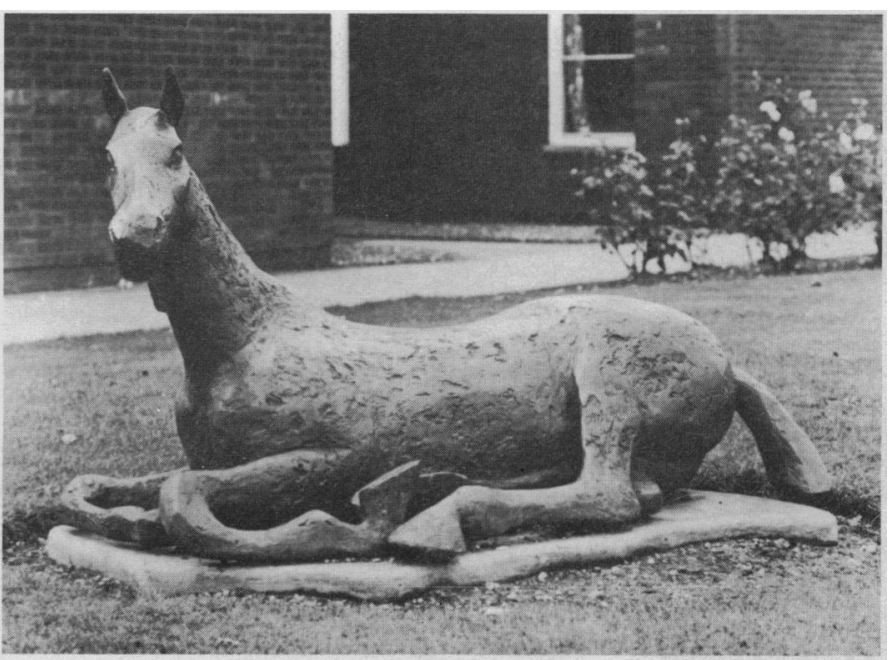

Sculptures: (left) "Pisces" by Jessie Watkins at the Royal Free Hospital, London, and (above) horse by Elizabeth Frink at the Queen's Medical Centre, Nottingham.

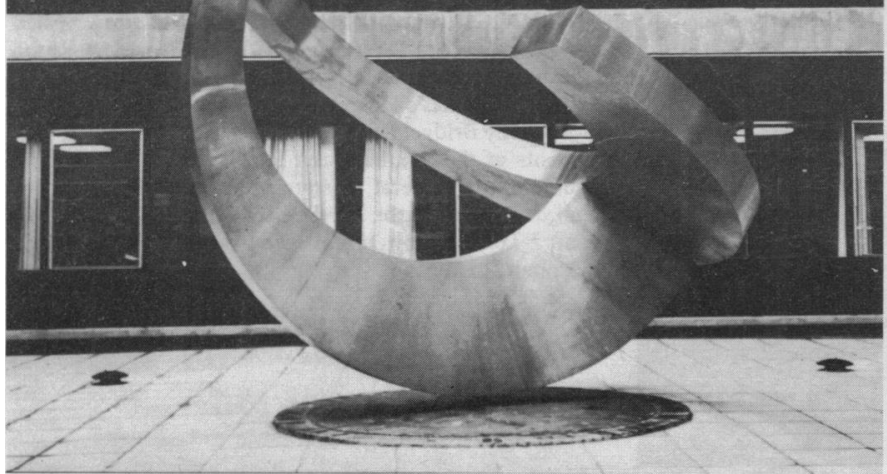



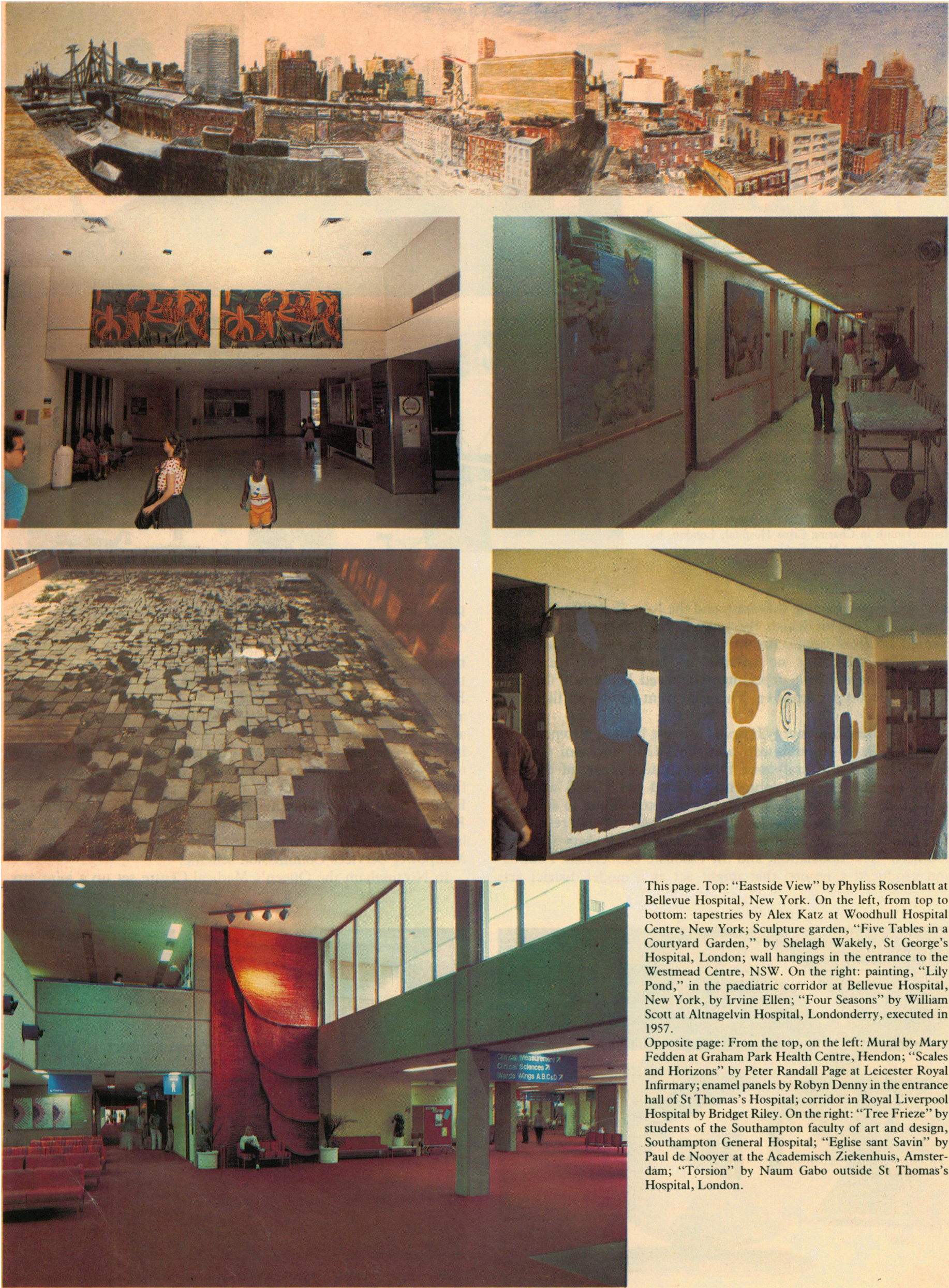

This page. Top: "Eastside View" by Phyliss Rosenblatt at Bellevue Hospital, New York. On the left, from top to bottom: tapestries by Alex Katz at Woodhull Hospital Centre, New York; Sculpture garden, "Five Tables in a Courtyard Garden," by Shelagh Wakely, St George's Hospital, London; wall hangings in the entrance to the Westmead Centre, NSW. On the right: painting, "Lily Pond," in the paediatric corridor at Bellevue Hospital, New York, by Irvine Ellen; "Four Seasons" by William Scott at Altnagelvin Hospital, Londonderry, executed in 1957.

Opposite page: From the top, on the left: Mural by Mary Fedden at Graham Park Health Centre, Hendon; "Scales and Horizons" by Peter Randall Page at Leicester Royal Infirmary; enamel panels by Robyn Denny in the entrance hall of St Thomas's Hospital; corridor in Royal Liverpool Hospital by Bridget Riley. On the right: "Tree Frieze" by students of the Southampton faculty of art and design Southampton General Hospital; "Eglise sant Savin" by Paul de Nooyer at the Academisch Ziekenhuis, Amsterdam; "Torsion" by Naum Gabo outside St Thomas's Hospital, London. 

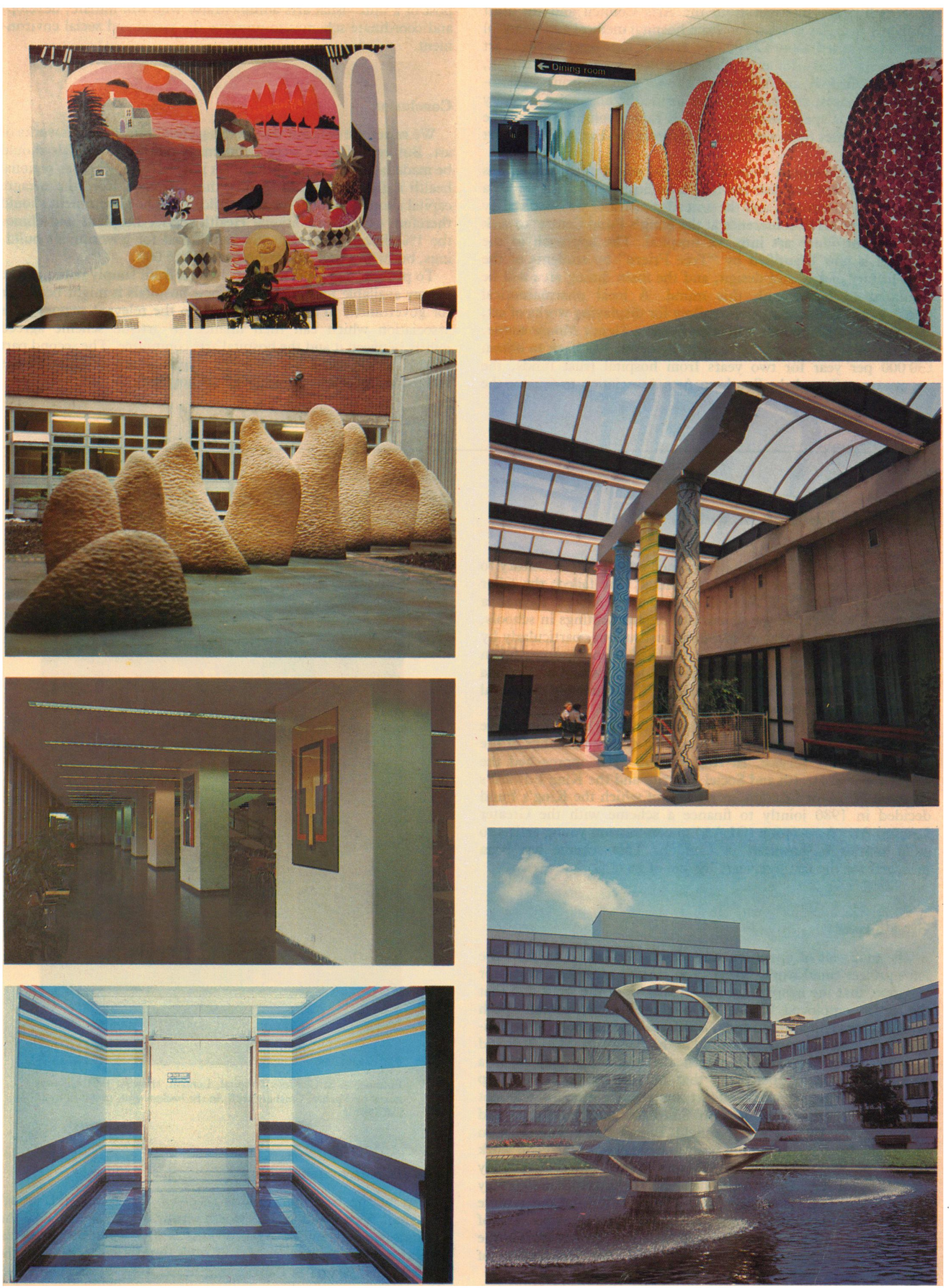

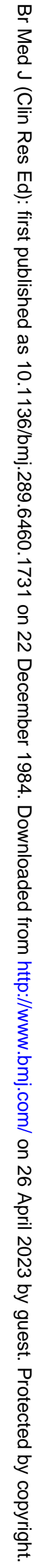


trust with representatives from the Arts Council and the East Midlands Arts Association and from hospital medical and financial staff. They raised about $£ 25000$ for three or four large works of art for external areas-for example, sculptures by Elizabeth Frink, Hubert Dalwood, and Gillian Wise-as well as prints, photographs, canvases, and tapestries for inside the hospital. Currently about $£ 5000$ is spent annually. Half is raised voluntarily and the remainder comes from matching funds from the East Midlands Art Association.

When Southampton General Hospital was built nothing was spent on art, but last year the health authority chairman set up a humanising committee, and the unit administrator was inspired by the Art in the NHS conference at the King's Fund Centre ${ }^{6}$ to seek funds to introduce art into the hospital. The approach to the cafeteria is now beautified by "Tree Frieze" by students of the local faculty of arts and design, and the main dining area will be repainted to blend with this mural. A local pharmaceutical company has financed a public gallery for displaying works of art, and the hospital grounds will soon house a Henry Moore statue. Southampton's unique achievement, however, has been to obtain $\$ 30000$ per year for two years from hospital trust funds, the county council, and the Southern Arts Association to finance the post of a unit visual arts administrator who will initiate, develop, and coordinate schemes to improve the visual and social environment.

\section{Conclusion}

We reject the concept that nothing should be spent on works of art. But even if there were a consensus that new hospitals should be made beautiful with works of art it is doubtful whether regional health authorities would finance this provision from the meagre capital allotted to them for new buildings. The government should therefore extend to National Health service hospitals and clinics the $1 \%$ allocation system now authorised for government buildings, but with a higher maximum than $£ 25000$.

To prevent this earmarked art budget from simply reducing the money available for constructing new hospitals it might be better for government to allocate this sum to the relevant regional arts association which can then finance an artistic scheme agreed jointly between it and the hospital arts committee. The second part of this article describes how one regional arts association has tackled the problem of public art in hospitals.

\section{Murals in London hospitals}

There have been at least two determined attempts this century to commission murals for London hospitals. One failed; the other thrives. In $1911 \mathrm{D} \mathrm{S} \mathrm{McColl} \mathrm{and} \mathrm{Charles} \mathrm{Aitken} \mathrm{formed} \mathrm{a}$ committee to promote the practice of mural paintings in schools, churches, hospitals, and other public institutions, particularly by young artists and students. Roger Fry had been unsuccessful in obtaining a mural commission at the London Hospital by Vanessa Bell, ${ }^{7}$ and in 1912 he held a competition. Unfortunately the mural paintings entered showed no real talent. ${ }^{89}$

One of us (JHB) had recognised the need for a central initiative to brighten with pictures the all too often dreary buildings of the National Health Service. In August 1979 JHB approached the Department of Health and Social Security and the King Edward's Hospital Fund for London, as a result of which the King's Fund decided in 1980 jointly to finance a scheme with the Greater London Arts Association (GLAA) to commission young artists to paint murals in hospitals in London. This scheme has been managed for the last five years by one of us (LG).

\section{Ground rules}

The first year of operation was seen as a pilot, to see how the joint project could work. Some basic ground rules were laid-for instance, that the hospital would actually want the work and that the artist employed should be technically competent. Both organisations committed funds, and GLAA undertook the organisation. The scheme was advertised in the King's Fund journal and hospitals were asked to approach the Fund for help with a commission. GLAA perceived that its role would be to help commission specific works of art for specific sites, a role not fulfilled by any other organisation. Simply buying paintings would duplicate the role of the Nuffield Foundation's Paintings in Hospitals. GLAA also did not want to overlap with the good work which the organisation SHAPE was doing; SHAPE, already funded by GLAA, concentrated its workshop activities in long stay geriatric and psychiatric hospitals. The King's Fund did reserve the right of independent action, to purchase, for example, sets of prints if the occasion demanded it. GLAA has recently created the Public Art Development Trust to handle the organisation of commissions in hospitals.

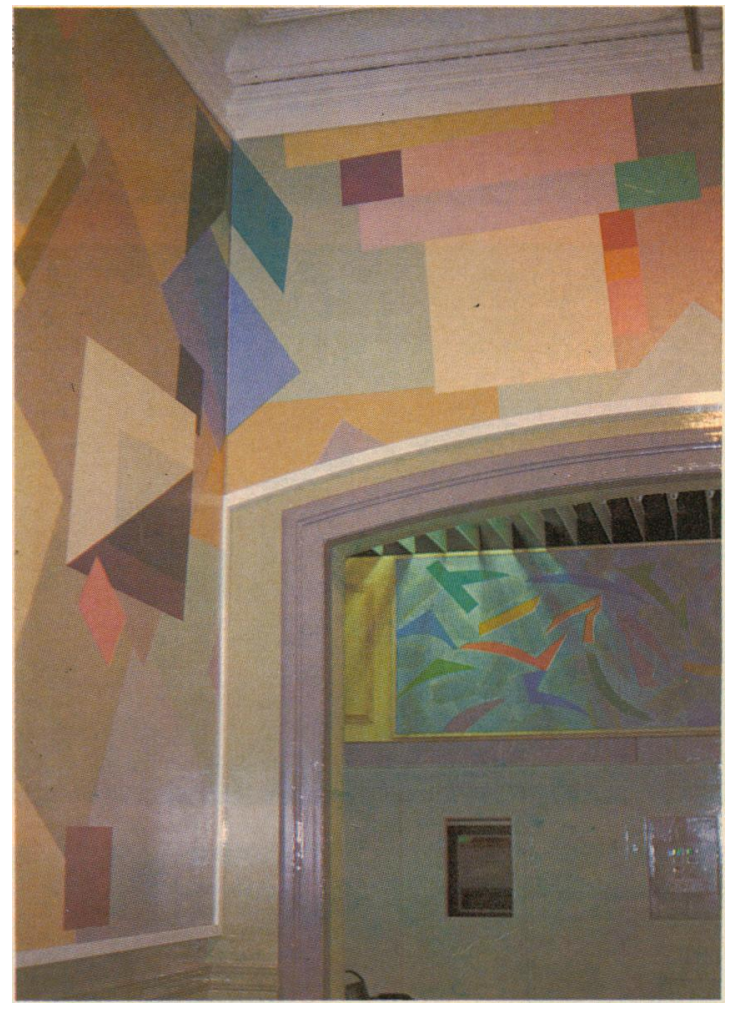

Entrance to St Charles's Hospital, London, showing 1981 staircase mural by Michael Ginsborg with, in the background, mural in front hall 1984.

\section{The St Charles commission}

One of the first applications received was from St Charles's Hospital, West London. It is worth setting down the details of this commission to show how the process works. After receiving the application representatives of the King's Fund (Geoffrey Phalp) and GLAA (LG) visited St Charles and heard from the staff how they 
wanted to brighten up the hospital's dreary interior. Although the hospital subscribed to the Paintings in Hospitals scheme, the pictures were insufficient alone to compensate for great corridors with dirty paint and gloomy Victorian interiors. Plans to beautify the hospital included the refurbishment of the entrance hall and reception, and after looking at a variety of alternative sites the King's Fund and GLAA suggested that most impact would be had by incorporating a mural in the entrance hall as part of the refurbishment. The plan was ambitious for the entrance hall was a very large high area, incorporating a flight of steps. The area was visually important for the hospital, but nurses, doctors, and visitors tended to speed through it on their way to wards. Nevertheless, here was a marvellous challenge for an' artist.

GLAA and the King's Fund committed funds for the artist's fee and materials and it was agreed to ask a small number of painters to submit ideas. LG presented the hospital with a series of slides of different artists' work-all of whom she thought would be professionally competent and would rise to the occasion. The artists Stephen Pusey and Michael Ginsborg were selected, and a third artist, Judith Francis, was proposed by a member of staff. The work of all three artists could not have been more different: both Stephen Pusey and Judith Francis were figurative painters and Michael Ginsborg was an abstract painter.

The artists were paid $£ 150$ for their proposals and these were exhibited in the hospital for users to comment on. The selection panel, consisting of an administrator, two consultants, the voluntary services organiser, and representatives of the King's Fund and GLAA were not surprised that Judith Francis's figurative idea was voted the most popular. Stephen Pusey had changed style and submitted an abstract work, based on loose flowing colours. Michael Ginsborg's idea was impressively designed with blocks of sympathetic colour decorating the whole foyer, in subtle but strong shades. This was the least popular submission with the general public, but was favoured by the selection panel. The panel considered that Judith Francis's detailed figurative work would be overlooked and lost on site. The judges therefore plumped for Michael Ginsborg's idea but commissioned Judith Francis to do some smaller panels for the visitors' suite next to this entrance.

To facilitate his painting Michael Ginsborg commissioned a full scale model of the hospital entrance foyer, employing art students to help. The painted canvases were then attached piece by piece to this. He repeated the process in public when he installed them in the hospital; this took nearly two weeks, during which time he was under fire from questions about what he was doing.

Despite a lot of criticism during this time, the commission has turned out to be an excellent choice. The entrance foyer now looks as fresh and spruce as the day the commission was completed, and the refurbished reception area, with a further painting by Michael Ginsborg over it, has given a new look to St Charles's Hospital."

\section{Other schemes}

The schemes which the King's Fund and GLAA have tackled have been remarkable for their variety. Commissions include a pair of brightly coloured tapestries for the outpatient waiting area of St Mary's Hospital, Sidcup, by Marta Rogoyska; a huge cutout enamel mural of birds and landscape by Graham Crowley for the outpatient waiting area of the Brompton Hospital; a painting by John Edwards for the entrance to Northwick Park Hospital; a sculpture garden with medicinal herbs by Shelagh Wakely for St George's Hospital, Tooting; an 86 foot long painting in four panels by Faye Carey for St Stephen's Hospital, Fulham; and other murals at the Brook, Central Middlesex, Newham, Queen Mary's, St Helier, and Westminster Hospitals.

It is a particular challenge to plan works of art at the design stage of a new hospital. At Newham the North East Thames Regional Health Authority considered including prints and paintings as part of the decoration scheme. They allocated money for this, which was supplemented by the King's Fund, GLAA, and the building contractor, French Kier Construction Ltd. The commissioning was deliberately varied. Anthony Eyton painted a large figurative "Beach Scene" for the entrance foyer and reception, Ray Walker painted two large panels, "Life and work in Newham," for the public snack bar; Jennifer Durrant produced an enormous abstract work for the staff dining area; prints were bought for the corridor walls. This impressive array has already proved its worth. In the snack bar the wallpaper has been torn off and graffiti scribbled on the bare walls; however, the more vulnerable unglazed paintings by Ray Walker are undamaged. The adage about paintings and prints saving the maintenance budgets of hospitals is, in this case, well proved.

All these schemes are characterised by a variety of approaches appropriate to the needs of the hospitals concerned. In many cases hospitals accepted the recommendations of the experts; in others general awareness was deliberately stimulated by a major competition. In all cases the public and staff have been invited to comment on exhibited proposals. Although not always favourable to the specific art on show, the comments have generally supported the idea of improving the interiors of hospitals. Dr Oliver Brooke, who has been responsible for major changes in St George's Hospital, Tooting, through his environmental improvement committee, is adamant that attention must be paid to such things at the very beginning. Too often art is used as Elastoplast for bad design and poor architecture. Dr Brooke is indicative of an increasing number of hospital staff who are aware of the adverse effects of a depressing environment on patients and staff. They are doing something about this—starting art and environment committees, raising funds from voluntary subscriptions and fund raising events, and making those funds go much further by bringing in organisations like the King's Fund and Public Art Development Trust to co-fund, advise, and help organise. It is time our hospitals looked good. Many people spend large parts of their lives in hospitals, often with a lot of time to wait, or think. "Art is able to provide solace, exhilaration, and satisfacton in a huge variety of different forms. Above all it is able to humanise a building, infusing an often soulless and impersonal environment with affirmation . . . many critical moments in our lives occur there-from birth through to death-and they ought to take place in surroundings which honour their true significance." 12

This article is based on information kindly supplied by those responsible for works of art in hospitals in many parts of the world. We thank: Mr B J Amos, Paramatta Hospitals, Australia; Professor W H Brummelkamp, Academisch Ziekenhuis, University of Amsterdam; Mr P Coles, Arts in Hospitals Research Project; Mr G M Criddle, Royal Liverpool Hospital; Dr D A Dreiling, Mount Sinai Medical Centre, New York; Mr J L Ellacombe, Mr B T Jackson, Miss P Mowbray, and Mr Eugene Rosenberg, St Thomas' Hospital and Special Trustees; Mr N C Evans, Royal Free Hospital; Professor H Hartveit, Haukeland Sykehus, Bergen, Norway; $\mathrm{Mr}$ M R Lager, Southampton General Hospital; Miss F Lamond, Northwick Park Hospital; Mrs D Levy, Miss K Melby, and Mr R Olsen, Bellevue Hospital Center, New York; Mr J J McLaughlin, Mr R Rohrich, and Mr D Wells, Health and Hospitals Corporation, New York City; Mr J R H Pepler, London Hospital; Mr G R Purland, Queen's Medical Centre, Nottingham; Mr S Reed, John Radcliffe Hospital, Oxford; Mr J A Rozzier, Charing Cross Hospital; Dr H-Reeve Sanders, Groote Schuur Hospital, Cape Town; Ms L J Shearing, St George's Hospital; Mr E Sinding-Larsen, Utsmykkingsfondet for Nye Statsbygg, Oslo; Professor C Sipponen, Jorvi Hospital, Finland; Miss C P Way and Mr R E Jefford, Addenbrooke's Hospital, Cambridge; Miss P R Tindale, chief architect, Department of the Environment; Miss L Willis, Leicester Royal Infirmary; and all those who have kindly provided photographs of art in their hospitals.

\section{References}

1 Baron JH. How to beautify your old hospital. BrMed $\mathcal{J}$ 1984;289:807-10.

2 Lydiate $\mathrm{H}$. The case for one percent: securing patronage for public art. In: Townsend $\mathrm{P}$. Ar within reach. Artists and craftworkers, architects and patrons in the making of public art. London: Art Monthly/Thames and Hudson, 1984:95-100.

3 Coles P. Art in the National Health Service. A report by the DHSS. London: DHSS, 1983.

4 Riley B. The Royal Liverpool Hospital Project. In: Kitson, A. Bridget Riley: the Royal Liverpool Hospital project. Liverpool: Walker Art Gallery, 1984

5 Coles P. Arts in hospitals: feasibility study for Isle of Wight Health District. London: DHSS, 1984

6 Hyslop R, ed. Conference report: art in hospitals. London: DHSS, 1984

Sutton D, ed. Letters of Roger Fyy. Vol 1. London: Chatto and Windus, 1972:351-2.

D'Offay A. The Omega workshops: alliance and enming in 1984:19-24 and plate 3. 1984:No. 5 .

10 Coles P. The Manchester arts project. London: Calouste Gulbenkian Foundation, 1981.

11 Baron JH, Hadden M. St Charles's Hospital: works of art. London: St Charles's Hospital, 1984

2 Cork R. Art and the National Health. Artline 1984;2(3):6.

,

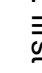

